\title{
A Produção Teórica sobre a Pobreza na Administração
}

\author{
The Theoretical Production about Poverty in Administration
}

La Produción Teórica sobre la Pobreza en la Administración

Guilherme Dornelas Camara Doutorado em Administração pela Universidade Federal do Rio Grande do Sul Professor Adjunto do Departamento de Ciências Administrativas da Universidade Federal do Rio Grande do Sul (UFRGS) http://lattes.cnpq.br/6175579588069044 https://orcid.org/0000-0001-5021-9535 guilherme.dornelas@ufrgs.b Escola de Administração da Universidade Federal do Rio Grande do Sul. Av. Washington Luiz, 855, sala 449, Centro Histórico, Porto Alegre, RS. CEP 90.010-

Maria Ceci Misoczky Doutorado em Administração pela Universidade Federal do Rio Grande do Sul Professora Titular da Escola de Administração da Universidade Federal do Rio Grande do Sul (UFRGS) e do seu Programa de Pós-Graduação http://lattes.cnpq.br/9637804118675867 https://orcid.org/0000-0003-2020-5882 maria.ceci@ufrgs.br

Resumo: $O$ artigo analisa a produção teórica sobre a pobreza no Brasil no campo disciplinar da Administração. A partir de critérios originados na Filosofia da Libertação, em especial de sua compreensão da Teoria Marxista da Dependência, foram pesquisados trabalhos sobre o tema publicados nos Anais dos EnANPADs e EnAPGs de 2004 a 2016. O objetivo é compreender como o tema da pobreza vem sendo debatido e apropriado pela Administração. Os resultados da pesquisa apontam para a consolidação dos estudos sobre a pobreza no campo da Administração e evidenciam a construção de um consenso ativo em torno da reprodução de ideologias dominantes centradas no mercado como dimensão central e organizadora da vida social e política.

Palavras-chave: Pobreza. Administração. Mercado.Filosofia da Libertação.
Abstract: The paper analyzes the theoretical production about poverty in Brazil in the field of Administration. Throughout criteria originated in the Philosophy of Liberation, specially in its comprehension of the Marxist Theory of Dependency, works published about this subject in the Proceedings of EnANPAD and EnAPGs from 2004 to 2016 were researched. The aim is to understand how the theme of poverty has been debated and appropriated in Administration.collective Management. The findings point out to the consolidation of the studies on poverty in the field of Administration and bring to evidence the construction of an active consensus around the reproduction of centered in the market as the organizing dimension of social and political life.

Keywords: Poverty. Management. Market Philosphy of Liberation.
Resumen: Este artículo analiza la produción teórica sobre la pobreza en el campo académico de la Administración. Basándose en criterios originados en la Filosofía de la Liberación, especialmente en su comprensión de la Teoría Marxista de la Dependencia, fueran investigadas ponencias publicadas sobre este tema en los Anales de los EnANPAD y EnAPGs desde 2004 hasta 2016. El reto del trabajo es comprender como el tema de la pobreza es incorporado y debatido en el campo de la Administración. Los resultados apuntan para la consolidación de los estudios sobre la pobreza en el área temática de la Administración y ponen luz a la construcción de un consenso activo alrededor de la reproducción de ideologías dominantes centradas en el mercado como dimensión organizadora de la vida social y política.

Palabras clave: Pobreza. Adminsitración Mercado. Filosofía de la Liberación.

Texto completo em português: http://www.apgs.ufv.br Full text in Portuguese: http://www.apgs.ufv.br

\section{Introdução}

O objetivo deste artigo é analisar o estado da arte da produção teórica sobre a pobreza no Brasil no campo disciplinar da Administração. Mais detidamente, analisar de que modo o fenômeno material da pobreza, urgente e incontornável no Brasil, é incorporado nos debates e ganha vulto no campo de conhecimento da Administração. Para isso, pesquisamos os textos publicados nos Anais dos Encontros da ANPAD (EnANPADs) e dos Encontros de Administração Pública e Governança (EnAPGs), devido à sua importância para a área. A periodicidade desses eventos possibilita acompanhar de modo mais sistemático as mudanças existentes nos estudos sobre a pobreza e o seu combate no país. A sua escolha para constituir a fonte dos dados, em detrimento de periódicos sobre o tema, deve-se, também, ao fato de que nesses encontros, assuntos pouco explorados ou emergentes entram em discussão mais rapidamente e podem ganhar vulto.

Delimitamos a pesquisa no período de 2004 a 2016, ou seja, desde a criação do Programa Bolsa Família (PBF) pelo Governo
Federal, através da Lei $n . \stackrel{0}{10.836}$ de 2004 , até a realização das últimas edições dos eventos já referidos. De acordo com o Governo Federal (Brasil, 2011, online), essa política social tem como objetivo superar a condição de pobreza em que parte do povo brasileiro vive, transferindo renda com condicionalidades na saúde e na educação. Os trabalhos apresentados nos EnANPADs sobre a pobreza e seu combate através do PBF somam 53 artigos. Estes ganham aumento de escala até de 2004, quando foram publicados dois artigos, até 2011, alcançando onze artigos. Desde então, esse número vem reduzindo paulatinamente, tendo sido publicados seis em 2012, quatro em 2013, três em 2014, quatro em 2015, um em 2016.

As pesquisas apresentadas nos EnANPADs e EnAPGs acompanham a implementação do PBF pelo Governo Federal e partilham suas definições elementares, como a definição técnica de pobreza visando à focalização das ações em um público-alvo específico. Os conceitos de pobreza e de miséria, ou pobreza extrema, foram definidos pelo Governo a partir de linhas de pobreza e de pobreza extrema que seguem a mesma medida estabelecida 
pelo Programa das Nações Unidas para o Desenvolvimento (PNUD). A linha de miséria foi fixada na renda mensal per capita de $\mathrm{R} \$ 70,00$, o que equivale a aproximadamente 1 dólar PPC (paridade poder de comprai) por dia. A linha de pobreza, por sua vez, ficou estabelecida em uma renda familiar de $\mathrm{R} \$ 140,00$ mensais per capita.

Como condição para receber os valores pagos mensalmente, as famílias beneficiárias devem manter as crianças e os jovens em idade escolar frequentes às aulas; os menores devem cumprir com o calendário de vacinação e as gestantes devem fazer os exames e consultas de pré-natal. As informações sobre o cumprimento das condicionalidades são fornecidas pelas Secretarias Municipais e Estaduais de Saúde e de Educação para o Governo Federal.

As famílias interessadas em participar do PBF devem estar inscritas no CadÚnico, um banco de dados que centraliza os cadastros dos beneficiários. As extremamente pobres recebem um Benefício Básico no valor de $\mathrm{R} \$ 85,00$ mensais, que é pago mesmo que elas não tenham crianças, adolescentes ou jovens. Esse valor pode ser complementado por um Benefício Variável (BV) de R\$ 39,00 mensais para cada filho, até o limite de cinco crianças e adolescentes até 15 anos. Para famílias com adolescentes de $16 \mathrm{e}$ 17 anos, é pago o Benefício Variável Vinculado ao Adolescente (BVJ), de $\mathrm{R} \$ 46,00$, até o limite de dois jovens. Com base nesses parâmetros, o valor percebido por famílias extremamente pobres pode variar de $\mathrm{R} \$ 85,00$ a $\mathrm{R} \$ 372,00$. Para as famílias pobres, com renda entre $R \$ 70,01$ e $R \$ 140,00$ mensais por pessoa, o Governo Federal transfere apenas o Benefício Variável e o Benefício Variável Vinculado ao Adolescente. Em 2012, foi criado o Benefício para Superação da Extrema Pobreza na Primeira Infância (BSP), pago às famílias com crianças de zero a seis anos que, mesmo recebendo os benefícios financeiros do PBF, continuam em situação de pobreza extrema. $O$ valor correspondente ao necessário para que a marca dos $\mathrm{R} \$ 85,00$ mensais.

O PBF é financiado pelo Fundo Nacional de Assistência Social, a partir de dotação específica no Orçamento da União. De acordo com a Lei $n^{\circ}$ 10.836, o Poder Executivo deve compatibilizar a quantidade de beneficiários do Programa com as dotações orçamentárias existentes. Em 2016, o Programa transferiu $\mathrm{R} \$ 28$ bilhões para cerca de 13,9 milhões de famílias (BRASIL, 2017). Além desse montante, uma parte dos recursos é destinada aos estados e municípios para apoio financeiro à gestão e execução descentralizada do PBF (Brasil, 2004). A Lei no 10.836 determina que, preferencialmente, os benefícios sejam pagos às mulheres, responsáveis pela inclusão das famílias no CADUN e pelo cumprimento das condicionalidades.

Em 2011, a focalização do PBF na população extremamente pobre, isto é, com renda per capita inferior a $R \$ 70$ mensais, foi fortalecida com o lançamento do Programa Brasil Sem Miséria (BSM), complementar ao Bolsa Família. Para atingir o objetivo de aumentar o acesso das famílias extremamente pobres aos serviços públicos, são realizadas visitas das Equipes de Saúde da Família nos domicílios, escolas e Centros de Referência em Assistência Social (CRAS) dos municípios. Desde então, o PBF passou a ser uma ação do que o Governo Federal chama de 'estratégia' BSM, articulando programas sociais criados especificamente para enfrentar as múltiplas aparências do fenômeno da pobreza. Subjaz a formulação de tais programas, uma visão fragmentada da realidade socioeconômica das pessoas que vivem em condição de pobreza ou pobreza extrema (miséria).

Outro objetivo é a inclusão produtiva, concebida como uma política transversal articulada às políticas setoriais de trabalho e microcrédito executadas pelo Ministério do Desenvolvimento Social e Combate à Fome e por Ministérios com os quais que ele convenia-se. No mesmo ano, o Governo Federal lançou o Programa Nacional de Acesso ao Ensino Técnico e Emprego (PRONATEC), vinculado ao Ministério da Educação, que prevê "uma série de subprogramas, projetos e ações de assistência técnica e financeira" com o "objetivo principal de expandir, interiorizar e democratizar a oferta de cursos de Educação Profissional e Técnica (EPT)" (Brasil, 2012). Ainda que o tema da inclusão produtiva seja muito interessante, os poucos trabalhos publicados sobre ele, em especial no campo da Administração, bem como o desmonte do PRONATEC pelo governo de Michel Temer, inviabilizam uma análise mais detida sobre a possibilidade desse Programa gerar efeitos consistentes ou duradouros para o combate à pobreza.

O referencial teórico consolidado, no âmbito do Bolsa Família, para compreender a pobreza e o modo como ocorre o seu combate no Brasil, mostram que o PBF articulou premissas que já eram vigentes sobre como a pobreza deveria ser combatida com novas proposições, unindo de modo bastante peculiar ideias liberais e socialdemocratas que, em um primeiro momento, podem parecer contraditórias. Não é de se espantar, portanto, que sejam esses marcos teóricos que dão sustentação aos estudos sobre a pobreza na Administração.

Sobre isso, cabe retomar Mézsáros $(2004 ; 2008)$ quando analisa as proximidades entre ciências sociais e ideologia. Ao afirmar aquela como legitimadora de princípios, ele afirma que "várias abordagens ideológicas contrastantes são compatíveis com os imperativos sociais geradores da ordem estabelecida". Nesse sentido, a aparente dicotomia entre categorias e lógicas liberais e outras socialdemocratas é uma falsa contradição de propostas que ocultam uma substância de classe idêntica que opera instrumentalmente mercado e estado como agentes que representam e garantem a realização de seus interesses.

A inexistência de um corpo teórico coeso e compartilhado pelos pesquisadores que se propuseram a estudar esse tema na Administração, não é, portanto, indício da falta de uma ciência normal no campo, do modismo do tema ou, simplesmente, de pouco rigor teórico. Pesquisas, de um lado, defensoras dos mecanismos de mercado como meio de sanar os problemas sociais e satisfazer as necessidades pessoais, e, de outro lado, autores que reconhecem a emergência de uma 'questão social' que precisa ser atendida pelo fortalecimento do aparato de governo e por uma cidadania ativa, mostram-se duas faces de uma mesma moeda. A pobreza, em ambas as visões, é tratada desde sua aparência. As relações causais das economias dependentes no capitalismo tardio, em se tratando de América Latina e, em nosso caso mais específico, de Brasil, não são questionadas. As soluções possíveis 
apresentadas pelas pesquisas não tem condições de ultrapassarem as barreiras da pura aparência, pois isso exigiria um questionamento sobre a essência do capital, a lei do valor, e a lógica da acumulação (Marx, 1988).

Assim, mesmo que involuntariamente, muitos pesquisadores convertem-se em representantes da ideologia dominante. Cabe destacar compreensão de ideologia proposta por Mészáros (2008:8, grifos do autor):

A ideologia, como forma de consciência social, é inseparável das sociedades de classe. Ela se constitui como consciência prática inescapável de tais sociedades, vinculada à articulação dos conjuntos de valores e estratégias rivais que visam ao controle do metabolismo social sob todos os seus principais aspectos. Os interesses sociais, que se revelam ao longo da história e que se entrelaçam de modo conflitante, encontram sua manifestação no plano da consciência social na grande diversidade do discurso ideológico, relativamente autônomo (mas de forma nenhuma, independente), com seu impacto poderoso mesmo sobre os processos materiais mais tangíveis do metabolismo social. O caráter reprodutor das pesquisas realizadas reforça a ideologia dominante reforça a sociedade de classes, naturalizando-a. Indiretamente, as pesquisas deixam de contribuir efetivamente para a mitigação das condições de vida dos pobres ao ignorar seu próprio caráter ideológico.

Para Mészáros (2004: 244, grifos do autor), "o pluralismo ideologicamente alardeado [pelos representantes da ideologia dominante] exclui radicalmente a legitimidade de uma contestação feita do ponto de vista da classe hegemônica alternativa e estruturalmente subordinada".

Desde essa problematização a respeito da relação entre ideologia e ciências sociais, sendo a Administração uma ciência social aplicada, é que buscamos compreender de que modo o tema da pobreza é incorporado nos debates acadêmicos na Administração, bem como identificar possíveis indícios de sua trajetória no campo. Para isso, realizamos uma pesquisa qualitativa exploratória. Analisamos os artigos publicados nos Anais dos EnANPADs e EnAPGs sobre a pobreza e seu combate no período 2004-2016 com o objetivo de compreender como o tema foi inserido na área e como se está construindo a apropriação da Administração sobre o tema.

Este artigo está organizado em quatro partes. Além dessa introdução, na próxima seção são revisados os autores e instituições que influenciam a produção intelectual nacional sobre o tema; na sequência, são apresentados elementos da Filosofia da Libertação que embasam nossa crítica às abordagens anteriores; depois são apresentados os procedimentos de coleta e análise de dados; em seguida, é analisada a construção teórica que vem sendo realizada na Administração para estudar a pobreza e seu combate por meio do Bolsa Família; ao final, são apresentadas algumas considerações.

\section{Principais referências para compreender a pobreza e seu combate}

Em um primeiro momento, identificamos que o Governo não definiu arbitrariamente a pobreza. Pelo contrário, agiu informado por técnicos e pesquisadores que se vincularam à produção teórica e a recomendações que circulam no contexto internacional acerca da pobreza, dos pobres e de como efetivar o seu combate. Essas recomendações originam-se e são disseminadas a partir dos países centrais e de organismos multilaterais. Dentre as principais referências, destacam-se as obras de John Rawls, Amartya Sen e Milton Friedman; e documentos oficiais do Programa das Nações Unidas para o Desenvolvimento (PNUD) e do Banco Mundial (BM). Essas constituem um corpo não coeso sobre a pobreza e como deve ser realizado seu combate. No entanto, apesar de não poderem ser justapostos, esses autores e instituições compartilham interpretações liberais centradas na ideia do pobre como um indivíduo destituído de oportunidades no âmbito do mercado. A essas perspectivas, é circunscrito o tema do desenvolvimento, entendido como crescimento econômico que pode ser adjetivado de diferentes maneiras: desenvolvimento mundial (World Bank, 1973); desenvolvimento humano (PNUD, 1990); desenvolvimento como liberdade (Sen, 2000).

Autores ligados a essa concepção partem da ideia de que o crescimento econômico não gerou o fim da pobreza (Friedman, 1966; World Bank, 1973; Sen, 2000) e que, portanto, é preciso ajudar os pobres a se ajudarem (World Bank, 2011). Em uma tautologia ampliada, esses autores e instituições reconhecem que os mecanismos de mercado postos, historicamente, não conseguiram resolver o problema da pobreza; sua proposta é expandir a abrangência desses mesmos mecanismos, de modo que façam caber neles aqueles que, até então, estiveram às suas margens.

Subjaz a esse imperativo moral, uma noção de sociedade bem ordenada, em que a liberdade de pensamento e de consciência, os mercados competitivos, a propriedade privada dos meios de produção e a família monogâmica são as instituições responsáveis pela distribuição dos direitos e deveres (Rawls, 2008). Nessa sociedade, os indivíduos possuem capacidades e oportunidades desiguais que tentam realizar por meio de funcionamentos valorizados individualmente. Portanto, empresas, organismos multilaterais, a sociedade civil organizada e os governos devem apoiar a inserção dos pobres nos mecanismos de mercado, desde que isso fortaleça os institutos tradicionais que distribuem direitos e deveres em uma sociedade de classes. Aí reside a essência da ideia de desenvolvimento como liberdade, isto é, na criação de oportunidades para que os indivíduos realizem suas capacidades por meio de funcionamentos por eles valorizados (Sen, 1997, 2000).

Para Sen (1997:1), as desigualdades entre os indivíduos podem ser prejudiciais para o funcionamento das sociedades, pois "a desigualdade é um ingrediente comum da rebelião, mas também é importante reconhecer que a percepção da desigualdade, e o conteúdo desse conceito, depende substancialmente das possibilidades de uma rebelião de fato". A partir de então, é possível pensar em uma abordagem das desigualdades econômicas que seja capaz de minimizar as possibilidades de revolta popular. Para tanto, Sen $(1997 ; 2000)$ propõe a adoção de mecanismos de empoderamento financeiro, realizada a partir de comparações entre indivíduos e visando reduzir às desigualdades.

Desde a perspectiva liberal, os Programas Sociais de Combate à Pobreza podem operar de dois modos. Por um lado, esses Programas oferecem uma renda mensal para os pobres e 
miseráveis, seguindo a lógica do imposto de renda negativo de Friedman (1966), que "enfrenta diretamente o problema da pobreza. Ajudando o indivíduo na forma que mais lhe é útil, com dinheiro. É o modo mais geral e poderia substituir uma série de medidas existentes na atualidade. [...] Cada dólar que se ganha significa mais dinheiro disponível para gastar" (Friedman, 1966:244). Por outro lado, os programas sociais devem investir em capital humano com a intenção de aumentar a produtividade dos trabalhadores. Becker (1993:15) define como capital humano a "educação formal, um curso de informática, gastos com cuidados médicos, palestras sobre as virtudes da pontualidade e da honestidade, pois eles melhoram a saúde e aumentam os ganhos dos indivíduos". Portanto, no PBF a obrigatoriedade da frequência escolar como condicionalidade visa proporcionar uma educação básica que torne as crianças capazes de seguir instruções e serem controladas (Sen 1997).

As políticas de transferência de renda proporcionam uma distribuição de dinheiro, de modo que o cumprimento de um imperativo moral gera, ao mesmo tempo, "escolhas e oportunidades para viver uma vida tolerável” (PNUD, 1997:15), expandindo os mecanismos de mercado. A partir desse referencial, o combate à pobreza seria operado pela ampliação das escolhas e das liberdades dos indivíduos nos mecanismos de mercado, espaço de realização pessoal.

Considerando o PBF desde esse referencial, é notório que o Programa manteve um certo conservadorismo na concepção da pobreza como um problema individual do pobre, com repercussão familiar que assola grande contingente humano. As considerações sobre a pobreza, feitas no bojo da ideologia liberal, associam economia e moral conservadora para responsabilizar os pobres por sua condição de vida, ao mesmo tempo em que visam docilizá-los às instituições tradicionais distribuidoras de direitos e deveres nas sociedades de classe.

No entanto, a essa premissa, foram incorporados elementos de um discurso socialdemocrata que defende a ampliação dos direitos sociais e a necessidade da afirmação da cidadania do pobre. Esse novo aspecto do combate à pobreza deveu-se à aproximação entre o Governo Federal e setores da sociedade que concebem a chamada 'questão social' desde a necessidade de avanços de direitos constitucionais já conquistados, com inspiração no Estado de Bem-Estar Social. Ao adotar pressupostos aparentemente diferentes da visão liberal, essa interpretação concebe a ampliação dos direitos sociais e o fortalecimento da cidadania como condição para a superação da pobreza. Há, nessa abordagem, a associação entre o fortalecimento dos mecanismos de mercado e uma mudança na condição política dos pobres, conduzida por políticas e departamentos de governo, com ou sem o apoio de empresas, ONGs e organismos multilaterais.

Os autores que tratam da questão social possuem em comum o pressuposto de que, na América Latina, o crescimento econômico orquestrado via desregulamentação do mercado exigiu o sacrifício da questão social (Ivo, 2006; Telles, 2006). Cabe ressaltar que a questão social não é uma abordagem uníssona. Os autores vinculados a essa interpretação compartilham referenciais e o pressuposto da insuficiência do neoliberalismo para dar conta da questão social, mas essa questão surge das inquietações que vêm sendo formuladas de formas diversas por autores que se debruçam sobre a realidade regional (Telles, 2006:53).

Autores que partilham dessa abordagem compreendem que a pobreza é produzida socialmente (Leguizamón, 2005), ao passo que a pobreza endêmica nos países latino-americanos não conseguiu ser superada pela globalização e transformação neoliberal que o capitalismo mundial aqui produziu. Autores vinculados a essa matriz socialdemocrata apontam os problemas sociais que a desregulamentação dos mercados e a fragmentação de direitos sociais e políticas públicas advogadas pelo liberalismo causaram. Para Leguizamón (2005:41), as causas da pobreza massiva na América Latina são: 1) "a impossibilidade de gerar renda pela via da condição de assalariado formal"; 2) "a reforma do mercado de trabalho, a flexibilização laboral e a falta de cobertura de direitos vinculados ao trabalho", como a seguridade social; 3) a impossibilidade de acesso a outros meios de subsistência, como "o acesso à terra, à água ou ao crédito".

Como resultado desse processo de transformação das condições de reprodução social, a sociedade não consegue traduzir direitos proclamados em parâmetros mais igualitários de ação. Para Telles (2006:88), isso é sinal de uma população destituída de seus direitos. "A pobreza brasileira não deixa, de fato, de ser enigmática em uma sociedade que [...] mal ou bem fez a sua entrada na modernidade e proclama, por isso mesmo, a universalidade da lei e dos direitos nela sacramentados". Ainda de acordo com essa autora, a persistência da pobreza tem raízes seculares, mas apresenta também uma face contemporânea, registrada no empobrecimento dos trabalhadores urbanos integrados nos centros dinâmicos da economia a partir dos anos 1990, como o fortalecimento dos mecanismos de mercado e o concomitante enfraquecimento da intervenção estatal em suas dinâmicas. Ainda que o Brasil, como os outros países da América Latina, não tenha tido um Estado de Bem-estar Social, os autores dessa abordagem parecem defender uma trajetória se volte a ele.

Os Programas de Transferência Condicionada de Renda são percebidos por esses autores como parte do substrato discursivo do desenvolvimento humano no marco da governabilidade neoliberal que aparenta preocupação com os pobres, mas que não promove a mudança das estruturas sociais nem das relações que produzem e reproduzem a pobreza e a exclusão (Leguizamón, 2005). Para Leguizamón (2005), os Programas são focopolíticas, isto é, um modo de governar preocupado com a provisão de mínimos que se traduzem em benefícios aos pobres, ao mesmo tempo em que reduzem os direitos sociais. Ainda que a autora não tenha tratado desse ponto específico, nos parece inevitável uma associação com a defesa de uma vida tolerável feita pelo PNUD (1997).

Para os autores vinculados à abordagem da questão social pela ótica socialdemocrata, o combate à pobreza deve ser situado desde uma perspectiva política que critique a degradação dos serviços públicos, o desemprego e as relações trabalhistas fragilizadas, visando à ampliação dos direitos sociais e a cidadania. Para eles, 
os pobres são "os não-iguais, os que não estão credenciados à existência cívica justamente porque são privados de qualificação para o trabalho. São os pobres, figura clássica da destituição. Para eles, é reservado o espaço da assistência social, cujo objetivo não é elevar condições de vida mas minorar a desgraça e ajudar a sobreviver na miséria" (Telles, 2006:94).

Os autores vinculados a essa interpretação defendem a ampliação do acesso aos Programas Sociais e a sua melhoria a partir da inclusão de parcelas da sociedade no seu planejamento. Assim, mais do que focopolíticas ou instrumentos compensatórios que pouco alteram a situação de vulnerabilidade, essas políticas poderiam favorecer a constituição de uma cidadania ativa, isto é, o exercício dos poderes de ação de sujeitos comprometidos com a comunidade a que pertencem de modo que, pela sua ação organizada, consigam algum tipo de eficácia política.

Para que haja uma compreensão mais clara dos avanços, efeitos e limitações do combate à pobreza no Brasil, via Programa Bolsa Família e Brasil Sem Miséria, é necessário cotejar as interpretações liberais e socialdemocrata da questão social com uma interpretação crítica do liberalismo e da socialdemocracia que tradicionalmente volta-se para o pobre e para a pobreza, criticando, ao mesmo tempo, a centralidade do mercado e a insuficiência de uma visão puramente política, sem considerações de suas raízes econômicas históricas, para a realização da vida humana. Encontramos na Filosofia da Libertação, de Enrique Dussel, o fundamento que torna possível empreender essa análise.

\section{Elementos da Filosofia da Libertação que embasam a crítica à ideologia dominante sobre a pobreza}

A Filosofia da Libertação constitui um arcabouço teórico importante para analisar a reprodução da pobreza desde as particularidades do sistema capitalista na América Latina. Dussel (2002:573), seu principal formulador propõe uma práxis orientada pelo princípio universal da "produção e reprodução da vida de cada sujeito humano", necessária "nesta época da história, no final do século XX e começo do III milênio, especialmente para as vítimas excluídas do atual processo de globalização do capitalismo mundial" (Dussel, 2002:572). Essa Filosofia articula uma ética, uma pedagogia, uma teologia, uma política e uma economia voltadas para a libertação dos pobres.

A Filosofia da Libertação está orientada pelo princípio éticomaterial da produção e reprodução da vida humana em comunidade (Dussel, 2002). Essa premissa não expressa apenas um 'direito à vida', mas coloca a 'vida' como única possibilidade de ser do humano. Assim, todas as ações, processos, estruturas e sistemas que atentem contra a 'vida humana' são seu contraditório. Tomando-a como fundamento, não cabe qualquer justificativa de atentado contra ela, em curto, médio ou longo prazo, mesmo que dentro do sistema moral vigente ela seja 'correta', 'válida' ou 'necessária'. A escolha preferencial pelo pobre feita por essa Filosofia justifica-se, pois, no capitalismo contemporâneo e, mais intensamente, nos países de economia dependente, os pobres vivem a negação da 'produção e reprodução da vida' em sua própria materialidade (Dussel, 2012).

Aqui cabe fazer um parêntese para situar o lugar do pobre na relação de capital, isto é, na apropriação capitalista do trabalho, atividade vital do trabalhador, como produtor de mais-valia (Marx, 1980). Obviamente, antes do capitalismo, a pobreza já existia. No entanto, com a expansão do modo de produção capitalista da vida, esta converte-se no imperativo de uma necessidade absoluta para o trabalhador: ter que vender a sua força de trabalho para garantir a produção e reprodução de sua vida e de sua família. Isso não é o caso exclusivo de um trabalhador hipotético, mas de todo o povo que não é proprietário dos meios de produção. Por isso, é mister compreender as dinâmicas que determinam a vida desse povo produtor como um povo trabalhador; povo que, ao produzir sua vida, no sistema do capital, contraditoriamente, a desgasta.

Marx (2007, p. 113) afirma que "[A] produção é também imediatamente consumo. Duplo consumo, subjetivo e objetivo: o indivíduo que, ao produzir, está desenvolvendo as suas capacidades, está também dispendendo-as, isto é, consome-as no ato da produção". Essa relação entre a produção e o consumo, ou seja, entre a própria objetivação e a subjetivação no processo de produção e reprodução da vida, não é a apropriação imediata do produto por aquele que o consome. $\mathrm{Na}$ realidade social, a distribuição interpõe-se entre o produtor e os produtos, mediante leis sociais. Com isso, a pobreza ganha novo fôlego, pois deixa de ser apenas uma condição de falta daqueles que são impelidos ao trabalho para o capital, mas também a impossibilidade prática de (re)produzir a vida. Sem o consumo, o ser humano não pode produzir. Como produção é realização, sem o consumo o homem não pode realizar. Por um lado, o consumo que permite ao homem apenas a sobrevivência, é um consumo que permite ao homem uma produção que não chega a realização. Por outro lado, o consumo dos produtos, convertido em razão-de-ser na sociedade inviabiliza a realização do ser humano, posto que toda a produção será pautada pelo consumo e o consumo ditará a produção. A contradição entre trabalho e capital, portanto, é determinante para a proposição desta Filosofia.

Abordar a pobreza e o debate acadêmico sobre ela, desde essa perspectiva, exige evidenciar a natureza relacional da produção social da pobreza, isto é, que a pobreza é o correspondente de um processo de acumulação de riqueza. Esse pressuposto surge da constatação das condições de vida de dois terços da população da América Latina, frente à pujança de uma minoria (Dussel, 2002). Assumir a relação entre pobreza e processo de acumulação de riqueza impõe a materialidade desse vínculo para a análise dos Programas Sociais de Combate à Pobreza, pois, a indissociabilidade entre esses extremos remonta à origem do sistema do capital, ou melhor, ao processo de acumulação existente desde seu limiar. É de se destacar que o trabalho não é sempre capital. Enquanto trabalho vivo, potência criadora, este não-é capital; é sua Exterioridade. A partir de seu ser, o capital "descende à população para 'apreendê-la' em seu fundamento. De fato, na essência do capital está a produção de mais-valia. Como mais-valia absoluta, como massa de mais-valia, requer mais trabalhadores - 
aumenta a população" (Dussel, 2012: 343).

As próprias contradições do sistema (e aqui remetemos às notas de Marx sobre o empobrecimento e a superpopulação) impedem que todos estejam incluídos na sua Totalidade de um modo objetivamente concreto. $O$ desenvolvimento da maquinaria e a organização do processo de trabalho contribuem para uma diminuição do tempo necessário e, de modo correspondente, da população subsumida como assalariada. Essa superpopulação, o pobre, o pauper, como Marx o chama, é agora conceptualizado em sua relação de Exterioridade ao capital. Existe, para esses que não atingem os postos de trabalho oferecidos pelo capital, apenas a oportunidade de viverem às margens do sistema, como Marx (2007: 110) afirmava:

no conceito de trabalhador livre já está implícito que ele mesmo é pauper: pauper virtual [...]. Se ocorre que o capitalista não necessita da mais-valia do operário, este não pode realizar seu trabalho necessário, produzir seus meios de subsistência. Então, somente os obterá pela esmola [...]. Portanto, virtualitier [virtualmente], é um pauper.

Na condição de pauper excluído da relação de trabalho, esses sujeitos obtêm o necessário para as suas vidas apenas porque Ihes são jogadas esmolas da riqueza produzida.

O horizonte ontológico da classe trabalhadora - mesmo que não-assalariada, pobre, excluída - estabelece o desde-onde fazer a crítica à Totalidade do sistema capitalista, pois ao tomar o capital como fundamento para a realidade do trabalho nas sociedades capitalistas contemporâneas, o trabalho é uma determinação do capital e o trabalho vivo é alienado a este. Dussel (2012: 350) estabelece uma relação de proximidade, um cara-a-cara entre o capitalista e o trabalhador, no qual

a imediata corporalidade do trabalhador $[. .$.$] se enfrenta com o rosto$ do capitalista, primeiro em abstrato (desde um ponto de vista econômico), depois em concreto (em uma hermenêutica existencial), mas ao mesmo tempo como duas classes, duas raças, dois povos. A esse homem, que violentamente coagido por condições objetivas que dissolveram as suas relações de apropriação com a terra, com os instrumentos e com os outros homens, presente em seu próprio corpo, frente ao capitalista, só resta, para não morrer de fome, vender-se a si mesmo, vender a sua capacidade de trabalho por um certo tempo.

Nos países latino-americanos, o processo contemporâneo de acumulação de riquezas tem como contexto a globalização das economias e o reforço da relação de dependência dos capitais desses países em relação aos centrais. Dussel (2002) compreende que a transferência de valor, que está no centro das relações de dependência, analisadas por pensadores da Teoria Marxista da Dependência, como Gunder Frank (1969) e Marini (2005), originase da exploração de uma classe sobre a outra. Essa transferência de valor começa a ganhar forma no processo produtivo, pois é na produção de mercadorias que o valor que será transferido é criado. Portanto, para que se possa compreender o modo como a transferência ocorre é necessário conhecer as particularidades do trabalho nas economias periféricas.

De acordo com Marini (2005:143), essas economias são marcadas pela divisão internacional do trabalho, consolidadas após as independências formais dos países da região, que determina $o$ sentido do seu desenvolvimento. É desde então que se configura a dependência, entendida como "uma relação de subordinação entre nações formalmente independentes, em cujo marco as relações de produção das nações subordinadas são modificadas ou recriadas para assegurar a reprodução ampliada da dependência". Para o autor, a consequência da dependência não pode ser, portanto, nada mais do que maior dependência, e sua superação supõe necessariamente a supressão das relações de produção nela envolvida. De modo a tentar diminuir as perdas decorrentes desse mecanismo de transferência de valor, as nações desfavorecidas criam mecanismos de compensação visando ao incremento do valor trocado. Para conseguir o aumento do valor produzido, os capitalistas das economias dependentes devem lançar mão de uma maior exploração da força de trabalho, "seja através do aumento de sua intensidade, seja mediante a prolongação da jornada de trabalho, seja finalmente combinando os dois procedimentos" (Marini, 2005:153) Esse processo que reconhece Marini (2005) pode acontecer nos países de economia central, sendo mais intenso nos países de economia dependente, como os da América Latina.

O autor identifica três procedimentos operados pelos capitalistas nesse mecanismo interno de compensação das trocas desiguais. Em síntese, os três procedimentos identificados são a "intensificação do trabalho, o prolongamento da jornada de trabalho e a expropriação de parte do trabalho necessário ao operário para repor sua força de trabalho". Nos dois primeiros casos, o trabalhador é obrigado a um dispêndio de força de trabalho superior ao que deveria proporcionar normalmente, "provocando assim seu esgotamento prematuro"; no terceiro caso, é retirado do trabalhador a possibilidade de consumo do estritamente indispensável para conservar sua força de trabalho em estado normal. "Em termos capitalistas, esses mecanismos significam que o trabalho é remunerado abaixo de seu valor e correspondem, portanto a uma superexploração do trabalho" (Marini, 2005:156).

Nesse sentido, o efeito das trocas desiguais entre as nações é o de exacerbar o afã do capitalista por lucro e aguçar os métodos de extração de trabalho excedente. A superexploração do trabalho decorre de articulações complexas entre os três procedimentos apontados e configura a base que as economias dependentes latino-americanas adotaram para seu regime de acumulação. Este, por sua vez, é o correspondente regional do processo de acumulação vigente nos países centrais que se realiza, em parte, pelas trocas desiguais entre esses países e os dependentes.

Com o exposto, temos a Filosofia a Libertação como marco teórico para elaborar uma crítica às interpretações liberal e socialdemocrata da pobreza e do seu combate. Na interpretação liberal, a pobreza é um problema individual e o desenvolvimento, entendido como crescimento econômico, constitui uma etapa anterior e necessária à sua superação. $\mathrm{Na}$ interpretação socialdemocrata da questão social, o combate à pobreza é compreendido desde a urgência da afirmação de direitos sociais e de uma cidadania ativa, por intermédio de programas de governo e políticas públicas. Para a Filosofia da Libertação, no contexto das economias dependentes, a pobreza generalizada do povo é resultado do processo de acumulação capitalista e a sua superação exige a eliminação da superexploração do trabalho e a práxis do povo. Cabe, agora, analisar como essas interpretações influenciam 
na concepção e desenvolvimento do tema da pobreza e de seu combate no campo disciplinar da Administração.

\section{Procedimentos da Pesquisa}

O método de organização e análise dos dados seguiu os procedimentos indicados a seguir, orientados pelas formulações do Círculo de Bakhtin (ou Bajtín, como nas referências em língua espanhola). A partir da categoria de intertextualidade, Bakhtin (1984), podemos compreender como os elementos discursos repetem-se e relacionam-se em textos distintos, evidenciando o caráter ideológico da produção acadêmica sobre determinado assunto. Partindo da compreensão da intertextualidade de textos escritos e discursos, conseguimos superar o isolacionismo com o qual os trabalhos são compreendidos nas áreas acadêmicas, evidenciando a adesão das áreas a determinados temas, em uma conformação de uma consciência prática que adere à ideologia dominante, conforme os termos de Mészáros (2004; 2008). A intertextualidade, segundo Bajtín" (1997: 27), "é uma categoria operativa da filosofia da linguagem no materialismo histórico".

Para ele, o materialismo histórico existe como caminho para quem pretende compreender o acontecimento do ser singular na totalidade das relações sociais. O autor defende que o materialismo histórico possibilita "a saída do mundo teórico, mais abstrato, para o mundo do postupok (ato necessário) de realização, histórico e responsável" (Bajtín, 1997: 28). A intertextualidade, enquanto categoria operativa da filosofia da linguagem de orientação materialista histórica, permite mostrar como diferentes textos reforçam, na área, as ideologias dominantes que orientam as discussões sobre a pobreza e seu combate.

De modo a evidenciar a intertextualidade presente no campo da Administração, optamos por delimitar a constituição do corpus a trabalhos que tivessem sido apresentados nos Eventos da Associação Nacional de Pós-Graduação e Pesquisa em Administração (ANPAD). Os textos analisados foram levantados a partir de pesquisa na ferramenta de busca do sítio eletrônico dessa instituição.

Em um primeiro momento foi feita uma busca pelo tema 'pobre', que trouxe como resultado também os temas 'pobreza' e 'pobres', em um total de vinte e cinco textos dos Encontros da ANPAD e de encontros de áreas temáticas. Desses, vinte e um textos eram publicados nos encontros anuais da ANPAD ou setoriais de Administração Pública (EnAPG); outros três textos eram de anos anteriores ao período delimitado para o levantamento e um artigo foi apresentado no Encontro de Administração da Informação (EnADI). Estes trabalhos últimos quatro trabalhos não foram incorporados ao corpus de análise. Fizemos uma busca também com termos tratados na trajetória do materialismo histórico, como pauperismo, lumpemproletariado (lumpemproletariat) e miséria. Nenhum resultado de pesquisa foi encontrado. Isso nos dá indícios de que, ainda que esses temas sejam tradicionais nas discussões no campo do materialismo histórico, na Administração, mesmo em sua vertente crítica, o tema ainda não vem sendo abordado com o devido destaque.
Em um segundo momento, foi feita nova busca com o termo 'Bolsa Família', conduzidos pela hipótese de que a discussão sobre a pobreza na área poderia passar pelo PBF em razão da relevância que o Programa ganhara nos discursos governamentais e da mídia de massa. Nessa rodada foram encontrados trinta e três apresentados em eventos da ANPAD. Para realizarmos a busca nos Anais dos EnAPGs utilizamos a ferramenta de pesquisa avançada disponível no sítio eletrônico da ANPAD. Os doze trabalhos encontrados foram incorporados ao corpus.

Na sequência, buscamos os arquivos eletrônicos dos Anais dos Encontros da ANPAD referentes ao período de 2004 a 2014, procedemos à organização do corpus de análise em um quadro que permitisse identificar título, autoria, ano de publicação, divisão acadêmica e realizamos a leitura de cada artigo, identificando as principais referências, o método (ensaio, pesquisa exploratória, estudo de caso) e destacamos as principais conclusões em uma analítica interpretativa baseada no referencial teórico consolidado. Elaboramos uma caracterização que possibilitasse aproximar textos com temas homogêneos e diferenciar temas concorrentes. Essa operação possibilitou encontrar vinculações entre os textos divulgados nos EnANPADs EnAPGs e as interpretações abordadas na seção anterior sobre a pobreza e seu combate no Brasil. Textos que se repetiam em razão da alteração dos termos de busca foram identificados e destacados. Ao final, tínhamos cinquenta e três artigos publicados nos eventos da ANPAD.

A construção de corpus ocorreu a partir do delineamento em termos de relevância, homogeneidade e sincronicidade entre os trabalhos que se aproximavam. Os assuntos identificados como prioritários nos artigos analisados eram teoricamente relevantes e tinham um foco temático específico. Desse modo, os materiais foram agrupados de forma homogênea do ponto de vista da substância material dos dados; os blocos de material selecionado eram sincrônicos, possibilitando o reconhecimento de sua inserção histórica. Começou a se delinear a sustentação de algumas ideias recorrentes, em eco às abordagens liberal e social democrata, apresentadas anteriormente. Os temas que se repetiam ou relacionavam diretamente foram destacados. Dentre eles, não podemos deixar de mencionar ao menos três: a gestão do programa, o fortalecimento dos mecanismos de mercado e a precarização do trabalho.

\section{Apresentação e Análise dos Resultados}

Ao todo, cinquenta e três artigos publicados nos Anais dos Encontros da ANPAD (EnANPADs) sobre o tema da pobreza e o seu combate a partir do Programa Bolsa Família (PBF) no período 2004-2016. Trinta e dois foram publicados na divisão acadêmica APB - Administração Pública do EnANPAD, três em Gestão Ambiental e Social, três em Marketing, dois em Gestão de Pessoas e Relações de Trabalho, um em Operação de Serviços, um em Sistemas de Informação. Outros doze trabalhos foram apresentados nos EnAPGs.

Os trabalhos elaborados no início do período analisado focavam no pobre em perspectiva individual e ideal, sem 
correspondência à materialidade, concebendo-o como um sujeito hipotético a quem faltavam oportunidades. Trabalhos desse tipo tratavam o pobre como empreendedor (Gonçalves \& Feitosa, 2004; Slomski et al., 2004; Feitosa \& Gonçalves, 2005) ou como um consumidor com problemas financeiros (Mattoso \& Rocha, 2005). Nesses textos, a condição de vida na pobreza é uma externalidade que tende a ser superada com a facilitação do (micro)crédito e o desenvolvimento de programas de marketing voltados para esses consumidores marginais.

O entendimento de que o pobre é um empreendedor individual ainda permanece em trabalhos mais recentes, como o de Fonteles et al. (2011:8), para quem "se por um lado há determinação e a força de vontade que impulsionam alguns a empreender, por outro, há o medo de uma denúncia e até mesmo a falta de iniciativa para empreender de alguns que se prevalecem da receita fixa mensal proporcionada pelo programa". Em comum, esses trabalhos apresentam uma concepção inerente de desenvolvimento como crescimento econômico, evidenciando o papel do governo como financiador de ações de empreendedorismo social (Santos \& Carrion, 2009; Licio, Mesquita \& Curralero, 2010). Em suma, advogam a inclusão dos marginalizados nos mecanismos de mercado, via ação governamental, como meio de incrementar a economia e gerar riquezas.

A partir de 2006 a maioria das pesquisas deixou de lado a perspectiva do pobre. No que se refere à coleta e à análise de dados, ficou evidente que o estudo de caso foi estabelecido como o método principal. Nos trabalhos que analisamos, a pobreza foi tomada como dada ou como um pano de fundo em que o Bolsa Família e as estratégias locais complementares se desenvolvem. A ligação fraca entre o Programa e a justificativa de sua existência pode ser claramente identificada nos estudos que focaram na gestão, implementação e avaliação do Programa nas municipalidades, como em Silveira, Guerra e Pessanha (2013), ou na sua influência nos processos eleitorais, como em Rocha e Zuccolotto (2014). Os estudos de caso, ainda que possam ser relacionados uns aos outros em uma meta-análise, evidenciam o individualismo metodológico predominante na área que coloca em evidência supostos casos de sucesso mas, em contrapartida, perde de horizonte a totalidade das relações que conformam o modo como produzimos a vida. Esse é um dos pontos elementares do caráter ideológico desse campo de conhecimento.

Ganharam evidência, portanto, estudos sobre o Bolsa Família a partir da gestão, tema caro à Administração e parte de seu repertório analítico mais tradicional, como ilustra o trabalho de Silva e Monteiro (2012:11) que aborda o Índice de Gestão Descentralizada (IGD), que mede a eficiência e qualidade do PBF. De acordo com as autoras, esse índice "pode ser entendido como uma medida gerencial que tem permitido o fortalecimento da expansão de uma cultura de transparência e accountability na administração pública". Um trabalho que se destaca na oposição a essa abordagem é o de Leite (2013), que avalia o caso brasileiro em comparação com o programa similar, Oportunidades, do México em uma perspectiva neoinstitucional.

Para dar conta de alguma definição básica de pobreza, até então praticamente inexistente na área, muitos trabalhos adotaram as formulações de Rocha (2004; 2006), indicando uma linha de pobreza a partir da qual se delimitaram quem são os pobres, a exemplo de Vinhais e Souza (2006) e Fonteles et al. (2011). Essa abordagem traz reminiscências das recomendações de Friedman (1966), do PNUD (1997) e do Banco Mundial (2001) sobre o tema.

A intertextualidade (Bakhtin, 1984) dos trabalhos indica que, na Administração, a pobreza é concebida como uma questão multidimensional (Bronzo, 2006; 2008; Marin et al., 2012), localmente situada (Cardoso et al., 2006; Filho \& Silveira, 2006; Denubila, Ferreira \& Monteiro, 2010; Oliveira, Resende \& Vilas Bôas, 2010; Santos, 2011; Mourão, Ferreira \& De Jesus. 2011; Cisne, 2012), marcadamente feminina (Moreira, Lima \& Lopes, 2011) e com impactos significativos no meio-ambiente (Serrano, Neto \& Nogueira, 2012). Ainda que essa concepção aponte para uma aparência verossímil da pobreza no Brasil, ela não dá conta de alguns de seus elementos estruturantes, como a negatividade imposta pelo capitalismo à vida dos trabalhadores e, em especial, ao exército de reserva em sua forma de produção e reprodução; o machismo que fortalece uma divisão sexual do trabalho que incrementa a superexploração do trabalho das mulheres; e as questões relacionadas ao racismo.

Essas definições acompanham a trajetória conceitual presente na interpretação liberal da pobreza, com especial aderência às formulações do Banco Mundial e do PNUD, que concebem o combate à pobreza como uma estratégia que possibilita ajudar os pobres a se ajudarem (World Bank, 2011). A aderência de pesquisas à interpretação liberal do combate à pobreza, marcadamente prescritiva e normalizadora, leva à reprodução da lógica predominante nessa abordagem em um cenário de total ausência de reflexividade.

Alguns trabalhos apresentaram o que consideravam opções viáveis para mitigar a reprodução da pobreza: o empoderamento (Bronzo, 2006, 2008; Moreira, Lima \& Lopes, 2011; Matta, Moreira \& Silva, 2012) e o incremento de capital humano e social (Helal \& Neves, 2006; Ferreira, Jimenez \& Holzer, 2011; Guerra et al., 2012). Neles, a solução da pobreza passa pelo aumento das oportunidades e pela realização da justiça social através da incorporação de indivíduos nos mecanismos de mercado. Essas asserções indicam receptividade dos pesquisadores às formulações e recomendações de John Rawls, Amartya Sen, do PNUD e do Banco Mundial, ainda que muitos autores da Administração não os tenha citado em seus trabalhos. Essa é uma dimensão da intertextualidade que indica a penetração da ideologia dominante na área e a sua reprodução, ainda que não intencional, pela academia.

As condicionalidades também são contempladas pela penetração da abordagem liberal nas pesquisas sobre o Bolsa Família. Elas são tratadas como uma espécie de aposta nas políticas de transferência de renda capaz de proporcionar aos beneficiários um futuro de "escolhas e oportunidades para viver uma vida tolerável" (PNUD, 1997:15). Para alguns autores, as condicionalidades estariam vinculadas um necessário aumento do capital humano, pois "em longo prazo, a não acumulação do capital 
humano causado por escolaridade baixa e saúde precária é uma consequência negativa grave de trabalho infantil, representando uma oportunidade perdida para melhorar a produtividade e a capacidade de ganhos futuros da próxima geração" (Guerra et al., 2007:8). Outros autores vinculam as condicionalidades do PBF ao capital social. Para Helal e Neves (2006:6), ele é o determinante da pobreza e "o fato de um indivíduo pertencer a grupos ou associações, ou seja, a rede de relacionamentos (capital social) lá desenvolvida por este indivíduo passa a afetar positivamente a probabilidade dele escapar da pobreza”. Esse raciocínio, ainda que coerente em termos formais, desconecta a pobreza das condições de uma sociedade de classes e, ainda que tenham um apelo moral, contribuem para obscurecer a ameaça antiética à produção e reprodução da vida humana, de acordo com os termos da Filosofia da Libertação (Dussel, 2002; 2004).

Entretanto, as limitações dessa interpretação liberal do combate à pobreza se mostra presente nas considerações finais dos próprios textos que as divulgam. Os autores parecem reconhecer que o empoderamento, o capital humano e o capital social são, se muito, determinantes parciais da pobreza. Como afirmam Moreira, Lima e Lopes (2011:13), “o empoderamento econômico, avaliado como fundamental para a emancipação das mulheres, é alcançado apenas parcialmente". Na mesma direção, Guerra et al. (2012:12) apresentam o incremento do capital humano como um benefício das condicionalidades, para logo em seguida afirmarem que "não há nenhum controle do real rendimento escolar destas crianças. Este pode se apresentar como um ponto falho, uma vez que não há uma preocupação sistemática com o ensino e, sobretudo, a aprendizagem destas crianças, mas simplesmente, com a frequência escolar". Essas ilustrações permitem constatar que apesar de certo incômodo, os autores não levam adiante as possibilidades que seriam abertas para a reflexão mais consequente sobre seus achados. Faz frente a essa abordagem um ensaio teórico de Andrade (2013), que analisa o processo de controle das condicionalidades ponderando sobre o seu caráter punitivo.

A intertextualidade entre os trabalhos permite identificar uma crítica às formulações liberais consolidadas na área. Elas questionam os alcances da ampliação dos mecanismos de mercado por si mesmos, denunciam a precarização do trabalho no Brasil e defendem o fortalecimento das políticas públicas, compartilhando de concepções da abordagem socialdemocrata da questão social. Para os autores vinculados a essa interpretação, caberia, urgentemente, sanar os resultados nefastos das décadas de política neoliberal a partir de estratégias que haviam dado certo nos países centrais em décadas anteriores sem, contudo, ameaçar a estabilidade político-econômica dos países na economia de mercado globalizada.

Desde essa visão, a questão social foi incensada por ideais do Estado de Bem-Estar Social e a ideia do pobre como marginalizado, proposta por Castel (1997) foi retomada, colocando em evidência o signo da vulnerabilidade. Para superar a situação da vulnerabilidade dos marginalizados, pesquisadores do tema clamam pela necessidade de garantia dos direitos sociais e pela viabilização de uma cidadania ativa, via participação cidadã e acesso a políticas públicas. De acordo com os autores dessa abordagem, o pobre não é apenas alguém com parcos recursos vivendo em situação de vulnerabilidade socioeconômica às margens da sociedade, mas um sujeito político destituído de seus direitos e de sua cidadania.

Bronzo (2006; 2008; 2011), Filho e Silveira (2006), Chaves, Monteiro e Sucupira (2007), Mendes, Barbosa e Rodrigues (2007) e Matta, Moreira e Silva (2012) trouxeram à discussão a articulação entre a oferta de um benefício monetário, o empoderamento financeiro e o capital humano, a institucionalização dos direitos sociais à luz da Constituição de 1988 e o atingimento de uma cidadania ativa por parte dos beneficiários do Bolsa Família.

Chaves, Monteiro e Sucupira (2007:13) destacam que "se um dos objetivos é implementar a renda básica de cidadania então é preciso expandir a cobertura do Benefício Básico paulatinamente até alcançar a totalidade da população e aumentar o valor referente desse benefício para que seja no mínimo suficiente para a subsistência". Mas como ainda não há um consenso, "se o objetivo for estimular alguma mudança comportamental ou cultural por meio das transferências de renda condicionadas, então essas devem ser respeitadas e conferidas apesar de toda a dificuldade nesta avaliação já amplamente discutida". A defesa da subsistência, tomando como ponto de análise o critério material da produção e reprodução da vida em comunidade, permite-nos ver que essa proposta, aparentemente contrária à liberal, na verdade reformula a ideia de garantir que os pobres vivam uma vida tolerável (PNUD, 1997).

Ainda no que se refere às possibilidades de mudanças nas condições de vida, Santos et al. (2016) afirmam que para beneficiários do Programa, o risco de saída do emprego é de 7 a $10 \%$ menor do que para não-beneficiários. No entanto, as considerações são ainda bastante exploratórias.

Consubstanciando a discussão sobre a ampliação dos direitos sociais e a instituição de uma cidadania ativa a partir da implementação do Programa, Mendes, Barbosa e Rodrigues (2007:12) afirmam que "o PBF, ao disponibilizar recursos para alimentação e ao exigir a manutenção da criança na escola, poderá, no futuro, retirar da situação de pobreza em que se encontram os seus ascendentes". Contudo, não se estabelece "uma relação democrática entre governantes e cidadãos possibilitando, assim, a participação cidadã e fortalecendo o capital social” (Mendes, Barbosa \& Rodrigues, 2007:11).

No mesmo sentido, Ferreira (2010:12) afirma que

o Bolsa Família exerce efeitos positivos sobre as condições de vida das famílias, em virtude da profunda vulnerabilidade a que estão sujeitas, relacionada com a precária forma de inserção no mercado de trabalho. Fica patente a frágil experiência dos sujeitos em relação ao acesso aos direitos e à regulação estatal, de modo geral[...]

Em geral, os artigos publicados nos EnANPADs ficam centrados em temas caros à gestão, como: modelagem de gestão (Cardoso et al., 2006; Chaves, Monteiro \& Sucupira, 2007; Escobar, 2008; Calvacante \& Ribeiro, 2010); auditoria operacional (Ribeiro, 
2007; Torres \& Torres, 2011); avaliação de modelos de gestão (Silva \& Monteiro, 2012) e avaliação da eficiência do Programa (Pedroso \& Calmon, 2009; Denubila, Ferreira \& Monteiro, 2010; Ferreira, Jimenez \& Holzer, 2011; Souza, Pereira \& Delgado, 2011; Sá \& Silva, 2012; Silva \& Monteiro, 2012).

O número de trabalhos apresentados na divisão acadêmica de Administração Pública indica que esse é considerado o espaço por excelência do tema da pobreza e de seu combate, principalmente respeitando a matriz socialdemocrata da questão social. Ao considerarmos os trabalhos publicados em outras divisões, fica evidente que elas compreenderam a pobreza e o seu combate a partir do arcabouço conceitual típico de cada área. No Marketing, o pobre é concebido como um tipo peculiar de consumidor - repleto de expectativas e desejoso pela inserção financeira (Hemais et al., 2011; Segabinazzi \& Lumertz, 2011), o que é coerente com a abordagem do desenvolvimento humano, ainda que os autores não façam registro de sua apropriação. Em Gestão de Pessoas e Relações de Trabalho os dois trabalhos apresentados giraram em torno do empobrecimento da classe trabalhadora devido aos processos de automatização e flexibilização nas empresas (Faria \& Sant'Anna, 2006; Campos, Urbina \& Lago, 2008). Na área de Finanças, Campara, Vieira e Potrich (2105) afirmam que os beneficiários do Programa têm boa satisfação global de vida, apesar de baixo bem-estar financeiro. Esses trabalhos apenas tangenciam aspectos que poderiam ser relacionados à superexploração do trabalho, contudo não se apropriam do conceito para discutir o empobrecimento da classe trabalhadora.

Não há registro de trabalhos sobre a pobreza ou o seu combate nas divisões acadêmicas de Ensino e Pesquisa em Administração e Contabilidade, Estratégia em Organizações, e Gestão de Ciência, Tecnologia e Inovação, nem em Estudos Organizacionais. É interessante destacar que a ausência de trabalhos nessa última divisão pode ser uma indicação a mais do fato de que nela prevalece a definição de organização como ente estruturalmente formalizado, e a rejeição à consideração da organização como processo ou como organização da economia política.

Tendo em vista que, mesmo nos trabalhos que adotam a abordagem da questão social predominam artigos que fazem análises pontuais e voltadas para as funcionalidades do Programa, não é de surpreender que a interpretação da Filosofia da Libertação, em sua apropriação filosófica da Teoria Marxista da Dependência (TMD), não encontrou eco nos trabalhos pesquisados. Mesmo a libertação na perspectiva educacional, representada pela proposta pedagógica de Paulo Freire, que tem sido recentemente apropriada pela Administração, não foi referida nos trabalhos pesquisados. A contribuição de Josué de Castro (1951; 1953), outra referência nacional de importância destacada no debate internacional sobre a fome e a pobreza, também tem sido negligenciada pelos estudos da área. Assim, a consolidação dos estudos sobre a pobreza e o Bolsa Família no campo da Administração evidencia $\circ$ abandono de esforços para compreender e conceituar a pobreza a partir de nossa situação particular, encontrando-se a predominância do que Guerreiro Ramos (1958) chamava de transplante de ideias alienígenas de forma não-reflexiva e contribuindo, desse modo, para a construção de um consenso ativo em torno da reprodução das ideias hegemônicas centradas no mercado como dimensão central e organizadora da vida social e política.

\section{Considerações Finais}

A pobreza e seu combate levado a cabo por meio do Bolsa Família estão imbricados diretamente na precarização das condições de produção e reprodução da vida do povo brasileiro. Contudo, isso acontece de modo compósito. Apesar do Programa oferecer um incremento no orçamento familiar, capaz de suprir necessidades mais imediatas de alimentação e moradia, o valor do benefício não altera as condições de vida dos beneficiários, mantendo-os em uma situação de vulnerabilidade similar à que estavam antes de serem incorporados aos Programas. No contexto socioeconômico atual do País, onde aumenta o desemprego e intensificam-se soluções de orientação neoliberal para a crise cíclica vivida, fica evidenciado o caráter paliativo do PBF, incapaz de resolver a miséria estrutural do povo brasileiro.

A apropriação da pobreza e seu combate para o campo disciplinar da Administração não passou incólume pelos traços mais conservadores da área. Para tornar a pobreza um tema da Administração, adequaram-na ao formato e ao arcabouço teórico predominantes na área. A Filosofia da Libertação permitiu identificar que na Administração a pobreza e seu combate têm sido tratados como problemas técnicos. Em quase sua totalidade, os trabalhos analisados subestimaram o aspecto histórico e econômico da pobreza, suas causas estruturais e os efeitos da pobreza e seu combate para o povo, evidenciando a necessidade de que os estudos sobre o tema se aprofundem tanto no aspecto teórico quanto no rigor metodológico se quisermos contribuir para a produção de conhecimento em substituição à mera operacionalização, reprodução e disseminação das proposições das ideologias dominantes.

A análise que empreendemos de pesquisas sobre o Programa Bolsa Família tomou como referência a Filosofia da Libertação e sua compreensão da Teoria Marxista da Dependência para formular críticas às perspectivas liberal e socialdemocrata da questão social. Foi constatada a reprodução de abordagens que levam à afirmação que, no Brasil, a pobreza decorre decorrente de um problema individual de acesso à renda, como afirmam o Banco Mundial e Friedman; da impossibilidade de realizar capacidades valorizadas, como propõe Sen; de desigualdades que não favorecem a todos, como na teoria da justiça de Rawls; e pode ser combatida com a ampliação dos direitos sociais e com a instituição da cidadania, como propõem os autores que tematizam a questão social. A ausência de estudos que tomam autores que elaboraram suas proposições sobre a realidade brasileira e latino-americana a partir de suas particularidades na totalidade do sistema do capital, não permite a discussão da relação entre reprodução da pobreza e acumulação de riqueza. Enquanto essa dimensão continuar negligenciada, as contribuições teóricas da Administração sobre o tema serão inautênticas, reduzindo a área à reprodução das ideologias dominantes. 


\section{Referências}

Andrade, F. (2013). Entre o incentivo e a punição: uma análise do processo de controle do programa Bolsa Famíla. In: XXXVII EnANPAD, 2013. Anais... Rio de Janeiro.

Bakhtin, M. (1984). Problems of Dostoievsky's poetics. Austin: Texas University Press.

Bajtín, M. (1997). Hacia uma filosofia del acto (ético). De los borradores. Y otros escritos. San Juan: Universidad de Puerto Rico.

Bauer, M.W.; Aarts, B. (2002). A construção do corpus: um princípio para a coleta de dados qualitativos. In: Bauer, M.W.; Gaskell, G. (Eds.) Pesquisa qualitativa com texto, imagem e som: um manual prático. Petrópolis: Vozes, p. 39-63

Becker, G. (2008). Human Capital. The Concise Encyclopedia of Economics. Library Economics and Liberty. Indianapolis: Liberty Fund. Disponível em: <http://www.econlib.org/library/Enc/HumanCapital.html>. Acesso em: 17 abr. 2012

Brandão, A. (2011). Perspectivas para os celulares dos pobres servirem a políticas de inclusão financeira e de governo eletrônico: a proposição do Ministério do Desenvolvimento Social no Governo Lula. In: XXXV EnANPAD, 2011. Anais... Rio de Janeiro.

(2012). Eficiência Operacional e Avanços da Logística de Pagamento e de Cartões do Programa Bolsa Família. In: XXXVI EnANPAD, 2012. Anais... Rio de Janeiro.

Brasil (2004). Presidência da República. Casa Civil. Lei no 10.836, de 09 de janeiro de 2004. Brasília, 2004. Disponível em: <http://www.planalto.gov.br/ccivil_03/_ato2004-2006/2004/lei/l10.836.htm>. Acesso em: 12 jan. 2013.

(2012). Ministério da Educação. Programa Nacional de Acesso ao Ensino Técnico e Emprego. O que é o PRONATEC. Brasília: 2012. Disponível em: <http://pronatecportal.mec.gov.br/pronatec.html>. Acesso em: 17 abr. 2013

(2017). Portal da Transparência do Governo Federal. Transferência de Recursos por Ação de Governo. Brasília: . Disponível em: <http://www.transparencia.gov.br/PortalTransparenciaPesquisaAcaoUF.aspc odigoAcao $=8442 \&$ codigoFuncao $=08 \&$ NomeAcao $=$ Transferenc $\% E 7 \% E 30+d$ e+Pobreza+e+Extrema+Pobreza+\%28Lei+\%BA+10\%2E836\%2C+de+2004 \%29\&Exercicio=2011 >. Acesso em 13 mar. 2017.

Bronzo, C. (2006). Políticas locais de inclusão social, autonomia e empoderamento: reflexões exploratórias. In: XXX EnANPAD, 2006. Anais... Salvador.

(2011). Vulnerabilidade, empoderamento e proteção social. Reflexões a partir de experiências Latinoamericanas. In: XXXII EnANPAD, 2008. Anais... Rio de Janeiro.

Serviços sócio-assistenciais e a redução das vulnerabilidades: desafios e limites da proteção social. In: XXXV EnANPAD, 2011. Anais... Rio de Janeiro.

Campara, J.; Vieira, K.; Potrich, A. (2015). Satisfação Global de Vida X BemEstar Financeiro: Desvendando a Percepção de Beneficiários do Programa Bolsa Família. n: XXXIX EnANPAD, 2015. Anais... Belo Horizonte.

Campos, G.; Urbina, F.; Lago, J. (2008). El Trabajo o la Pobreza... Quedó la Explotación. In: XXXII EnANPAD, 2008. Anais... Rio de Janeiro.

Cardoso, F. et al. (2006) Modelando o Programa Bolsa Família: Estudo Comparativo entre os Municípios de Duque de Caxias e Cabo Frio, no Estado do Rio de Janeiro. In: XXX EnANPAD, 2006. Anais... Salvador.

Castro, J. (1953). Geografia da Fome. 4 ed. Popular. Rio de Janeiro: Casa do Estudante.

(1951). Geopolítica da Fome: Ensaio sobre os problemas de alimentação e de população do mundo. Rio de Janeiro: Livraria-Editora da Casa do Estudante do Brasil.

Castel, R. (1997). A Dinâmica dos Processos de Marginalização: da vulnerabilidade à "desfiliação". Cadernos CRH, Salvador, n. 26:19-40, jan./dez.

Cavalcante, P.; Ribeiro, B. (2010). Descentralização do Programa Bolsa Família: Determinantes do Desempenho Municipal. In: IV EnAPG, 2010. Anais... Vitória.

Chaves, A.; Monteiro, M.; Sucupira, L. (2007). O Que Nos Diz o Desenho do Programa Bolsa Família. In: XXXI EnANPAD, 2007. Anais... Rio de Janeiro.

Cisne, J. (2012). Intersetorialidade como um Novo Paradigma para a Gestão Pública Focada em Resultado: análise dos projetos de combate à pobreza no Ceará. In: XXXVI EnANPAD, 2012. Anais... Rio de Janeiro.

Denubila, Laís; Ferreira, M.; Monteiro, D. (2010). Programa Bolsa Família: Análise Da Trajetória Dos Indicadores Sociais Em Minas Gerais. In: XXXIV EnANPAD, 2010. Anais... Rio de Janeiro.

Dussel, E. (2002). Ética da Libertação na ldade da Globalização e Exclusão. 2 ed. Petrópolis: Vozes.

Dussel E. (2004). Ética de la Liberación (Hacia el "punto de partida" como ejercicio de la "razón" ética originaria). In: Apel, K.-O.; Dussel, E. Ética del discurso y ética de la liberación. Madrid: Trotta, p. 269-290.

Dussel E. (2012). A Produção Teórica de Marx: um comentário aos Grundrisse. 1 ed. São Paulo: Expressão Popular.
Escobar, C. (2008). Governança Estratégica em Redes de Políticas Públicas: a Experiência do Programa Bolsa Família. In: III EnAPG, 2008. Anais... Salvador.

Faria, M.; Sant'Anna, A.(2006). Trabalhos Enriquecidos, Trabalhadores Empobrecidos? In: XXX EnANPAD, 2006. Anais... Salvador.

Feitosa, M.; Gonçalves, E. (2005). Os Empreendedores Pobres Falam: Fatores que Devem Ser Considerados para Facilitar o Acesso dos Mais Pobres ao Microcrédito. In: XXIX EnANPAD, 2005. Anais... Brasília.

Ferreira, M. (2010). Bolsa Família: uma experiência de acesso aos direitos e ao Estado? In: IV EnAPG, 2010. Anais... Vitória,.

Ferreira, M.; Jimenez, B.; Holzer, M. (2011). The impact of Public Management Performance of Conditional Cash Transfer in Quality of Life in Brazil. In: XXXV EnANPAD, 2011. Anais... Rio de Janeiro.

Filho, A.; Silveira, R. (2006). Um Modelo de Políticas Públicas Gerador de Renda, que Inclui os Marginalizados pela Informalização e Precarização do Trabalho: Uma Experiência Promovida pela Prefeitura Municipal de São Paulo. In: XXX EnANPAD, 2006. Anais... Salvador.

Fonteles, A. et al. (2011). Programa Bolsa Família e Mobilidade Social: Sociabilização, Trabalho e Educação nas Famílias Beneficiadas. In: XXXV EnANPAD, 2011. Anais... Rio de Janeiro.

Friedman, M. (1966). Essays in Positive Economics. Chicago: Chicago University Press.

Gonçaves, E.; Feitosa, M. (2004). Uma Investigação sobre os Fatores Que Afetam o Acesso dos Empreendedores Pobres ao Microcrédito na Perspectiva dos Gestores de Três IMFs (CEAPE, Banco da Mulher e Visão Mundial). In: XXVIII EnANPAD, 2004. Anais... Curitiba.

Guerra, A. et al. (2011). Programa Bolsa Família: uma análise do ponto de vista dos usuários. In: XXXV EnANPAD, 2011. Anais... Rio de Janeiro.

Guerreiro Ramos, A. (1958) A Redução Sociológica: introdução ao estudo da razão sociológica. Rio de Janeiro: ISEB.

Helal, D.; Neves, J. (2006). Superando a Pobreza: o Papel do Capital Social na Região Metropolitana de Belo Horizonte. In: XXX EnANPAD, 2006. Anais.. Salvador.

Hemais, M. et al. (2011). Visões do que é ser Pobre: Os caminhos do estudo da baixa renda na Economia e em Marketing. In: XXXV EnANPAD, 2011. Anais... Rio de Janeiro.

Holstein, J.; Gubrium, J. (2011) The Constructionist Analytics of Interpretative Practice. In: Denzin, N..; Lincoln, Y. (eds.). The SAGE Handbook of Qualitative Research. 4 ed. Los Angeles/London: SAGE, p. 341-358.

Ivo, A. (2006) Reconversão da Questão Social e a Retórica da Pobreza nos anos 1990. In: Cimadamore, A.; Dean, H.; Siqueira, J. (orgs.). A pobreza do Estado: reconsiderando o papel do Estado na luta contra a pobreza global. Buenos Aires: CLACSO Livros.

Licio, E.; Mesquita, C.; Curralero, C. (2010). Desafios para a coordenação intergovernamental do Programa Bolsa Família. In: XXXIV EnANPAD, 2010. Anais... Rio de Janeiro.

Leguizamón, S. (2005). Trabajo y producción de la pobreza em Latinoamérica y el Caribe: estructuras, discursos y actores. Buenos Aires: CLACSO Libros.

Leite, C. (2013) Disseminação de Políticas, Governos subnacionais, e organismos multilaterais: uma reflexão sobre a experiência do Programa Bolsa Família à luz do Programa Oportunidades. In: XXXVI EnANPAD, 2013. Anais... Rio de Janeiro.

Matta, I.; Moreira, N.; Silva, E. (2012). Empoderamento e Inclusão Social nas Ações do Programa Bolsa Famíla em Minas Gerais. In: XXXVI EnANPAD, 2012. Anais... Rio de Janeiro.

Mattoso, C.; Rocha, A. (2005). Significados Associados às Estratégias para Solução de Problemas Financeiros dos Consumidores Pobres. In: XXIX EnANPAD, 2005. Anais... Brasília,.

Marin, S. et al. (2012). A Concepção da Pobreza como Privação de Capacitações e as Políticas Públicas: uma Proposta de Medida Multidimensional para o Município de Silveira Martins - RS. In: V EnAPG 2012. Anais... Salvador.

Marini, R. (2005). Dialética da Dependência. In: Traspadini, R.; Stedile, J. (orgs.). Ruy Mauro Marini: vida e obra. São Paulo: Expressão Popular, p. 137180.

Marques, Vinícius et al. (2008). O Microcrédito e a Mitigação da Pobreza: uma Análise do Caso BNDES-Vivacred. In: III EnAPG, 2008. Anais... Salvador.

Marx, K. (2007). Elementos Fundamentales para la Crítica de la Economía Política (Grundrisse). 1857-1858. 20 ed. Ciudad de México: Siglo XXI.

Marx, K. (1980). O Capital(Crítica da Economia Política). Livro 1. O Processo de Produção Capitalista. Rio de Janeiro: Ed. Civilização Brasileira.

Mendes, V.; Barbosa, A.; Rodrigues, J. (2007). Gestão dos Serviços Públicos e Participação Cidadã: estudo com os Beneficiários do Programa Bolsa Família. In: XXXI EnANPAD, 2007. Anais... Rio de Janeiro.

Mézsáros, I. (2004). O Poder da Ideologia. 1 ed. São Paulo: Boitempo.

Mészáros, I. (2008). Filosofia, Ideologia e Ciência Social. São Paulo: Boitempo.

Monteiro, D.; Ferreira, M. (2008). Fatores Determinantes da Gestão do Programa Bolsa Família: Estudo do Índice de Gestão Descentralizada em Minas Gerais. In: XXXII EnANPAD, 2008. Anais... Rio de Janeiro. 
Moreira, N.; Lima, A.; Lopes, M. (2011). Dimensões do Empoderamento das Mulheres Beneficiárias do Programa Bolsa Família. In: XXXV EnANPAD, 2011. Anais...Rio de Janeiro.

Moreira, N.; Ferreira, M.; Matta, I. (2013). De um lado este carnaval, do outro este machismo total? Reflexões sobre gênero e Programa Bolsa Família. In: XXXVII EnANPAD, 2013. Anais... Rio de Janeiro.

Mourão, L.; Ferreira, M.; Jesus, A. (2011). Avaliação do Programa Bolsa Família em Favelas Cariocas. In: XXXV EnANPAD, 2011. Anais...Rio de Janeiro.

Novaes, F. (2010). O Bolsa Família no Contexto das Políticas Públicas. In: IV EnAPG, 2010. Anais... Vitória.

Oliveira, E.; Resende, T.; Vilas Boas, A. (2010). Situação de Risco e Pobreza em uma Cidade do Sul de Minas Gerais. In: IV EnAPG, 2010. Anais... Vitória. Pedroso, M.; Calmon, P. (2009). Avaliação da Eficiência Relativa das Capitais na Gestão Descentralizada do Programa Bolsa Família com a Utilização de Análise Envoltória de Dados (DEA). In: XXXIII EnANPAD, 2009. Anais... São Paulo.

Pinto, S. (2008). Dar o Peixe, mas Ensinando a Pescar. In: XXXII EnANPAD, 2008. Anais... Rio de Janeiro.

PNUD (1997). Programa das Nações Unidas para o Desenvolvimento. Human Development Report 1997. Disponível em: <http://hdr.undp.org/en/reports/global/hdr1997/chapters/>. Acesso em $21 \mathrm{fev}$. 2013.

PNUD (1990). Programa das Nações Unidas para o Desenvolvimento. Human Development Report 1990. New York: Oxford University Press, 1990. Disponível em: <http://hdr.undp.org/en/reports/global/hdr1990/chapters/>. Acesso em 21 jun. 2011.

Pochmann, M.(org). (2002). Desenvolvimento, Trabalho e Solidariedade: novos caminhos para a inclusão social. São Paulo, Cortez Editora, 2002.

. (2003). Outra cidade é possível: alternativas de inclusão social em São Paulo. São Paulo: Cortez Editora, 2003.

Ribeiro, B. (2007). Avaliação De Monitoramento Do Programa Bolsa Família Baseada Nas Fiscalizações Da Controladoria Geral da União. In: XXXI EnANPAD, 2007. Anais... Rio de Janeiro.

(2008) Monitoramento e Avaliação de Programas: Conceitos de Tipos de Avaliação e Uma Aplicação Prática do Programa Bolsa Família. In: III EnAPG, 2008. Anais... Salvador.

Rocha, S. (2006). Pobreza no Brasil: afinal, de que se trata? 3. Ed. Rio de Janeiro: FGV.

Rocha, S.; Albuquerque, R. (2004). Geografia da pobreza extrema e vulnerabilidade à fome. In: Velloso, J. P. dos Reis; Albuquerque, R (Orgs.). A nova geografia da fome e da pobreza. Rio de Janeiro: José Olympio, p. 3763

Sá, M.; Silva, L. (2012). Uma Análise da Aplicação do Programa Bolsa Família (PBF) no Município de São Bentinho - PB. In: V EnAPG, 2012. Anais... Salvador.

Santos, C.; Carrion, R. (2008). Microcrédito e Pobreza: um diálogo possível? In: XXXII EnANPAD, 2008. Anais... Rio de Janeiro.

Santos, D. et al. (2016). Os Efeitos do Programa Bolsa Família sobre a Duração do Emprego Formal das Pessoas Pobres. In: XXXII EnANPAD, 2016. Anais... Salvador.

Santos, N. (2011). Os Desafios da Gestão Intersetorial do Programa Bolsa

i O dólar PPC (paridade do poder de compra) "mede quanto uma determinada moeda poderia comprar se não fosse influenciada pelas razões de mercado ou de política econômica que determinam a taxa de câmbio. Leva em conta, por exemplo, diferenças de rendimentos e de custo de vida. É necessária para comparações de produtos internos brutos (PIBs). Com relação a 146 países abrangidos no cálculo em dólares PPC feito pelo Banco Mundial com dados de 2005, apenas 19 (todos eles entre os mais desenvolvidos) apresentam taxa inferior à verificada nas transações comerciais. Os Estados
Família: o Caso do Município de Guarulhos. In: XXXV EnANPAD, 2011. Anais...Rio de Janeiro.

Segabinazzi, R.; Lumertz, F. (2011) "Pobre espera o quê ?": Contabilidade Mental e expectativas de Atendimento de Indivíduos de baixa Renda. In: XXXV EnANPAD, 2011. Anais...Rio de Janeiro.

Sen, A. (1997). On economic inequality. In: FOSTER, James; SEN, Amartya. On economic inequality: expanded edition with a substantial annexe. Oxford: Clarendon Press. Letras.

(2000). Desenvolvimento como liberdade. São Paulo: Companhia das

Serrano, A.; Neto, J.; Nogueira, J. (2012). Poluição, Pobreza e Políticas Públicas. In: XXXVI EnANPAD, 2012. Anais... Rio de Janeiro.

Silva, A.; Monteior, D. (2012). Análise do Desempenho da Gestão Pública do Programa Bolsa Família em Minas Gerais por meio da Data Envelopment Analysis (DEA). In: XXXVI EnANPAD, 2012. Anais... Rio de Janeiro.

Silveira, A.; Guerra, A.; Pessanha, G. (2014). Desempenho na Gestão do Programa Bolsa Família na Microrregião de Varginha - MG: uma análise a partir do IGD no período de janeiro de 2007 a junho de 2013. In: XXXVIII EnANPAD, 2014. Anais... Rio de Janeiro.

Slomski, V. et al. (2004). A Controladoria e a Gestão Pública dos Programas Sociais: Um Estudos dos Impactos dos Programas Sociais na Renda Econômica e Financeira de Famílias Carentes no Município Três Lagoas MS. In: XXVIII EnANPAD, 2004. Anais... Curitiba.

Souza, J. L. (2008). Dólar PPC. O que é? Desafios do Desenvolvimento, IPEA, an. 5, n. 40, 11 fev. Disponível em $<$ http://www.ipea.gov.br/desafios/index.php?option=com_content\&view=articl e\&id=2146: catid=28\&ltemid=23>. Acesso em 22 nov. 2017.

Souza, L.; Pereira, D.; Delgado, V. (2011). Avaliação de Impacto da Ação de Lavoura do Programa Minas Sem Fome sobre a Renda Bruta Domiciliar Per Capita dos Agricultores Familiares de Minas Gerais. In: XXXV EnANPAD, 2011. Anais...Rio de Janeiro.

Spinelli, M.; Costa, B. (2008) Participação, Accountability e Desempenho Institucional: o caso dos conselhos de controle social do Programa Bolsa Família nos pequenos municípios brasileiros. In: III EnAPG, 2008. Anais.. Salvador.

Telles, V. (2006). Direitos Sociais: afinal do que se trata? 2 reimp. Belo Horizonte: Editora UFMG

Torres, F.; Torres, C. (2011). A Auditoria Operacional e o Aperfeiçoamento da Gestão Pública: O Caso do Programa Bolsa Família. In: XXXV EnANPAD, 2011. Anais...Rio de Janeiro.

Vinhais, H.; Souza, A. (2006). Linha Híbrida de Pobreza no Brasil Julho de 2006. In: II EnAPG, 2006. Anais... São Paulo.

World Bank. (1973). World Bank Group. Address to the board of Governors, by Robert S. McNamara. Nairóbi, Quênia, 24 set. 1973. Disponível em: <http://siteresources.worldbank.org/EXTARCHIVES/Resources/Robert_McN amara_Address

Nairobi_1973.pdf>. Acesso em 08 jul. 2012.

Disponível

(2001). World Bank Group. World Development Report. 2001.

<http://wwwwds worldbank.org/external/default/WDSContentServer/WDSP/l B/2007/09/12/000020953_20070912110712/Rendered/PDF/226840PORTU GUE1za20001200101PUBLIC1.pdf>. Acesso em 19 fev. 2013.

Unidos, país padrão do dólar, tem $P P C=1$. Todos os demais apresentam ganho no PIB em dólar PPC" (Souza, 2008, online).

ii M. Bajtín e Mikhail Bakhtin correspondem, respectivamente, às grafias em línguas espanhola e portuguesa de Михаи́л Бахти́н (1895-1975), filósofo russo. Quando utilizadas suas obras traduzidas ao português, optamos por adotar a grafia desta língua e fizemos o mesmo quando utilizamos suas obras traduzidas ao espanhol. 